\title{
FROM DIVINE COMMAND AND PROPHETIC GOALS TO SAPIENTIAL CHARACTER FORMATION: A SURVEY OF OLD TESTAMENT ETHICAL REFLECTION INFORMED BY PHILOSOPHICAL ETHICS ${ }^{1}$
}

\section{Abstract}

At first attention will be given to recent surveys of the study of Old Testament ethical reflection. Then it will be argued that the study of ethics in general can provide a theoretical frame according to which different modes of ethical reflection can be discerned in the Old Testament:

- A deontological 'Divine command' type of ethic rooted in the theophany on Mount Sinai through the communication of the Ten Commandments and the 'mitzvot'.

- A teleological or consequentialist type of ethic manifested in the prophetic emphasis on a covenantal relationship with God and other human beings.

- A perfectionist or virtue ethic found in later wisdom and priestly literature that aspires to be wise and holy.

- A descriptive ethic that focuses on the 'is' of Old Testament ethics then and not on the 'ought' of modern ethics now.

In conclusion, it will be suggested that more attention should be given to the dialogue between the study of biblical ethics and the meta-theory undergirding philosophical ethics.

Key Words: Old Testament Ethics; Deontological Ethics; Teleological Ethics; Perfectionist Ethics; Descriptive Ethics

\section{Introduction}

Old Testament ethics have been the less attractive stepsister of Old Testament studies for most of the twentieth century due to the following reasons:

A lingering perception that Old Testament ethical standards are somehow 'limited' due to the nature of ancient Israelite society (e.g. polygamy, subordination of women, slavery, etc.); or the priority that religious and theological considerations seem to have over ethical ones; as well as the Marcionite presupposition that neither an Israelite ethos or an Old Testament ethic can be applicable to Christians (Goldingay 1990:61-65). 
The complexity of the Old Testament is apparent to Biblical scholars who are deeply under the impression of the following difficulties: the co-existence of divergent sets of ethical or moral frameworks of interpretation (priestly, prophetic, wisdom, etc.); and the social, political and religious developments of almost a thousand years; as well as the role and influence of non-Israelite morality by not assuming Israelite ethical convictions to be unique (Wilson 1990:195-196).

The 'silence' of the Old Testament with regards to many modern ethical issues that were not prevalent two to three millennia ago deter many an ethicist who has no background in Ancient Near Eastern cultures to enable some conversation with those addressing current moral and ethical problems. Some of these current ethical dilemmas are abortion, pollution and the ever-widening gap between rich and poor.

Despite recent attention given to the ethos and ethics embedded in the Old Testament, Emily Arnd (2011:5-7) still identifies three 'stumbling blocks' for the use of the Hebrew Bible as a source for Christian Ethics. ${ }^{2}$ There are numerous 'interdisciplinary hurdles' which have to be addressed when engaging with the Old Testament on an ethical level where the study of an old text ancient languages and long dead cultures necessitate the cooperation of several academic disciplines; there is also the problematic negotiation between the study of the Hebrew Bible and other sources of ethical reflection that often result in the repudiation of the sacred scripture; the ancient and 'strange' character of the Old Testament does not allow easy and unproblematic conclusions to be made in the twenty-first century. ${ }^{3}$

In this contribution attention will be given to recent surveys of Old Testament or Hebrew Bible ethics. Thereafter an attempt will be made to use models utilized in current meta-ethical reflection to describe trends in Old Testament ethics in such a manner that it will allow more interdisciplinary discussion on the relevance of using ancient religious texts when considering current ethical dilemmas (Bosman 1994:259-266). A case will be made that one should not presuppose a linear development comprising three successive stages in Old Testament ethical reflection, but rather consider the possibility of the coexistence of the deontological and teleological ethics resulting in an ethical synthesis, i.e. a perfectionist mode of ethical decision making.

In conclusion it will be suggested that the process of character formation as reflected in the later priestly and wisdom texts may be of special significance for the theological-ethical discourse articulated in a morally eroded post-colonial Africa. ${ }^{4}$

\section{Recent Surveys of Old Testament Ethics}

Without disregarding the value of previous discerning surveys of Old Testament ethics by John Barton (1983), Robert R Wilson (1988), Eckart Otto (1991), Walter C Kaiser (1992)

2 Arnd (2011:5) is quite blunt when considering the possible relevance of the Old Testament in modern ethical discourse: "the claim that the treatment of the Hebrew Bible in contemporary Christian ethics is problematic is neither surprising nor original."

33 The concepts 'Old Testament' and 'Hebrew Bible' are used as overlapping terms according to the manner in which a specific author made use of it.

4 In the contribution as a whole, special attention will be given to recent attempts to describe what Old Testament ethics entail - i.e. American: B Birch, W Janzen \& W Kaiser; British: J Barton, EW Davies, CS Rodd \& C Wright; German/Swiss: W Eichrodt, J Hempel \& E Otto. 
and Rudolf Smend (1995); more attention will be given to the recent surveys made during the past decade by John Rogerson (2004) and Eryl Davies (2010). ${ }^{5}$

John Rogerson (2004:34) distinguishes between 'conservative' and 'liberal' approaches to the study of Old Testament ethics. The 'conservative' approach entails a high regard for the moral authority and even uniqueness of biblical texts, while the 'liberal' trend is much concerned with the cultural context of the Ancient Near East that has to be taken into account when considering its possible relevance for current theological-ethical discussion.

As one may expect Rogerson starts with his nineteenth century role model, WML de Wette, who made a major contribution to the theological-ethical study of the Pentateuch and Hexateuch. Rogerson (2004:58) is influenced by the theory of communicative interaction as formulated by the German philosopher Jürgen Habermas (1981) when he discerns aspects related to 'communicative interaction' in the Old Testament in the research done by De Wette in the first half of the nineteenth century. ${ }^{6}$ The combined influence of De Wette and Habermas leads Rogerson $(2004: 36,94)$ to argue that Old Testament ethical study should not interpret the Old Testament as a law book but as a reservoir of examples and not as precepts. According to Rogerson (2004:28) Old Testament discourses that appeal to the best in humankind form the bedrock for 'discourse ethics'.

It is important to note that Rogerson takes seriously both the history of Old Testament scholarship and Philosophy in general ${ }^{7}$. His attempt to combine theory and practice in Old Testament ethics is a challenging example of how his erudition about Old Testament scholarship and Philosophy can produce 'discourse ethics' that are potentially relevant for modern social issues (Rogerson 2004:81-133).

In one of the best recent surveys of Old Testament ethics, Eryl Davies (2010), investigated the manner in which biblical scholars have tried to deal with major ethical problems in the Old Testament by focusing on the morally troubling description in the Book of Joshua of the horrendous slaughter of the Canaanites by the Israelites during the entry into the Promised Land ${ }^{8}$. Before opting for a reader-response approach to the theological-ethical interpretation of the Old Testament, Davies (2010:2) points out in an even-handed manner the positive and negative aspects of several current models of biblical interpretation. ${ }^{9}$

During the closing phase of the nineteenth century and the first half of the twentieth century the so-called 'evolutionary approach' reigned supreme in Old Testament studies. The historical-critical study of the Old Testament allowed readers of the Bible to discern between older and younger sections in Scripture, as well as different theological trends (priestly, deuteronomic or deuteronomistic, wisdom, etc.). Morally offensive passages were

$5 \quad$ Recent surveys of Old Testament ethics by JK Bruckner (2003), BC Birch (2007) and CH Bullock (2008) have also been consulted and should be included in future more extensive surveys of this kind.

6 The discourse in the Old Testament that is relevant for modern ethical reflection ranges from conversations between God and Abraham (Gen 18) to the wisdom discourses in Ecclesiastes and Job.

7 The choice of Wilhelm de Wette as role model and his engagement with the communicative interaction theory of Jürgen Habermas are examples of his combination of history of Old Testament scholarship and Philosophy.

8 Davies (2010:1) makes it clear that the aim of his survey is "to examine some of the strategies that have been deployed by biblical scholars, past and present, in an attempt to come to terms with the ethically problematic passages of Scripture."

9 Amidst appreciation for the even-handed survey of past theological-ethical interpretations of the Old Testament by Davies (2010), one has to point out that his survey is more focused on the research done in Britain and the United States and less so in Germany - no reference is made of the significant theologicalethical studies and surveys conducted by Johannes Hempel (1938/1964, 1962), Hendrik van Oyen (1967) and Rudolf Smend (1995). 
often associated with the earlier, more primitive, religious thought amongst the Israelites. These older endorsements of violent behaviour, such as the extermination of the Canaanites, "belonged to an infantile stage in the moral progress of Israel." Older theological-ethical thought in the Old Testament was not the final word but was eventually "transcended in later Judaism and Christianity" (Davies 2010:139-140). This evolutionary interpretative strategy inculcated a negative approach to the Old Testament in general and caused the juxtaposition of a supposed vengeful and wrathful Lord God in the Old Testament with a loving and caring Jesus Christ in the New Testament. ${ }^{10}$

To some extent historical criticism also gives rise to the second approach to Old Testament ethics as advocated by the 'cultural relativists' who according to Davies (2010:140) "argued that the laws and institutions of ancient Israel were relative to their own time and culture, and were conditioned by their historical and socio-cultural location." This type of Old Testament ethics easily resolves "ethically problematic passages" by "emphasizing the historical particularity of the biblical prescriptions" and that "they merely reflected the social and historical milieu out of which they arose" (Davies 2010:141). Unfortunately the "cultural relativistic approach" tends "to alienate the ancient text from the modern reader" and this approach often makes the Old Testament and its ethical reflection "little more than an object of purely antiquarian interest."

Davies (2010:141-142) identifies the so-called "canon within the canon approach" as his third strategy that grapples with Old Testament ethics and it is clearly a response to the cultural relativist approach. It involves "a critical sifting of the ethical insights of the Hebrew Bible so that we can more easily extract those principles that have universal and abiding value from those that are merely particular and time-conditioned." Although this approach makes the daunting task of establishing some cohesion amongst Old Testament ethical reflection that developed over centuries more manageable, it is problematic due to its subjective nature since it "can easily be misused to support the vested interests of particular groups ... concerning anti-Semitism, sexual proclivity, gender equality, economic status or whatever." 11 No convincing criteria or reasons have been forthcoming in terms of which one can distinguish between biblical ethical injunctions that are valid or invalid for current ethical reflection.

In response to the "canon within the canon approach", Brevard Childs (1992:705) advocated the 'canonical approach' and described the task of the biblical interpreter as follows: "to reflect theologically on the whole of the Christian Bible in the light of the diverse biblical witnesses." Davies (2010:143) points out that the 'canonical approach' provides "a welcome corrective to the historical-critical method by which the Bible had become hopelessly fragmented, and its essential unity distorted or neglected." In addition, the 'canonical approach' reminds the interpreter that apart from the cultural context of biblical texts, as emphasized by the cultural relativists, the textual and theological-ethical context of moral indicators in the Old Testament must not be neglected. On the down-side of 'canonical criticism' it has not been convincingly argued why the 'final' or 'canonical form of the text' should be granted 'hermeneutical priority'. There are equally valid

10 Historical-critical study of the Old Testament has not been completely relegated to the dusty shelves of redundancy, but has made current scholarship aware of the possibility that "various stages of growth in the religious and ethical ideas of the Hebrew people" can be discerned (Davies 2010:140).

11 The theological-ethical support given to 'apartheid' during the twentieth century is an example of how vested interests thrive when linked to a 'canon within the canon approach' to the interpretation of Scripture. 
arguments for taking the canonical process prior to the formation of the 'final form' of the biblical seriously - as Sanders $(1972 ; 1980)$ proved quite conclusively. ${ }^{12}$

The next strategy to grapple with ethical passages of the Old Testament identified by Davies (2010:144-145) is the so-called 'paradigmatic approach' as advocated by Christopher Wright $(1983 ; 2004 ; 2005) .{ }^{13}$ According to Davies (2010:144) the most important goal of the 'paradigmatic approach' was "to make the Bible relevant to contemporary circumstances by drawing attention to the principles which underlie many of the customs and regulations of ancient Israel" and thus "making the Hebrew Bible adaptable to a wide range of moral problems, and enabled its practitioners to extract a surplus of meaning above and beyond what was explicitly articulated in the text. ${ }^{14}$ Serious problems arise when different interpreters identify diverging paradigms or principles in the same Old Testament texts. More troubling is the tendency to read the Old Testament to affirm the assumptions of the interpreter "about what is morally acceptable and unacceptable" (Davies 2010:145).

The 'reader-response approach' is the final strategy to engage with Old Testament ethics, discussed by Davies (2010:145-147) and also his personal preferred option. This approach was stimulated by a trend in literary criticism that coined the phrase, the 'resisting reader', who probed, questioned and resisted any statement that was morally offensive and unacceptable (Fetterley 1978). ${ }^{15}$ Therefore the 'reader-response approach' entails 'a salutary reminder that the biblical writers have their own axes to grind and their own agendas to promote, and contemporary readers need to compensate for this by reading 'against the grain' of the text (Davies 2010:146; Moyise 2004:95).

Eryl Davies (2010:146-147) advocates a type of 'reader-response approach' that is characterized by a 'moral and ideological critique' of the Old Testament that can be referred to as 'ethical criticism' that "meets the requirements of intellectual honesty and critical rigour, while at the same time being faithful to the concerns of the biblical writers." Davies (2010:147) concludes: "Such a reading, however, can only occur when we learn to regard Scripture as a conversation partner, sometimes congenial, sometimes cantankerous, but a partner, nonetheless, in a long-term conversation to which we are all invited to contribute."

In the following sections of this contribution, a conversation with philosophical ethics will be advocated as an important step to come to grips with Old Testament ethical reflection that is not done in isolation but with the 'intellectual honesty' and 'critical rigour' advocated by Eryl Davies above. It is therefore assumed that 'intellectual honesty' and 'critical rigour' should be established as part of an academic conversation between all

12 Davies (2010:144) concludes with a laudable note of caution with regards to the 'canonical approach' as advocated by Childs: "we cannot use the canonical strategy as a ploy to pretend that violence is only an incidental or peripheral feature of the Hebrew Bible which can be glossed over by emphasising the message of peace, love and forgiveness found in other parts of Scripture."

13 It may be useful to compare the use of the concept of 'paradigm' as used in the ground-breaking monograph by Thomas Kuhn, The Structure of Scientific Revolutions, with studies on Old Testament ethics that made use of the concept of paradigm (1962:210).

14 For example: a paradigmatic approach to the 'lex taliones' in the Old Testament goes beyond a literal 'eye for an eye' interpretation, by introducing the paradigm of proportionality "whereby the severity of the punishment must accord with the gravity of the offence" (Davies 2010:145).

15 The important role of the reader in the hermeneutical process of interpreting texts has been highlighted by invaluable contributions by Iser (1974), Fish (1980), Eco (1981) and Jauss (1982). 
disciplines concerned. This is all the more true about the study of Old Testament ethics that often shied away from academic interaction with philosophical ethics in the past. ${ }^{16}$

\section{Deontological or Divine Command Ethics in the Old Testament}

Deontological ethics decides on an act being right or wrong in terms of the character of the act and not its outcomes. Therefore an act can be considered to be inherently good or evil, without taking into consideration what the consequences of the act are (King 2008:220,245).

This implies that the moral duty to do something, or refrain from doing, emanates from the nature of the act and not from the consequences produced by the act. In this vein Kant formulated his categorical imperative that we have an unconditional duty to do what was considered morally right without any regard for its consequences - both for one's self as well as for others (Uleman 2010).

In the Old Testament, apodictic law can be used as an example of deontological ethics and the Decalogue as a manifestation of divine command ethics (Ex 20; Deut 5). Walter Eichrodt (1933-39) combined the 'natürliche Volkssitte' that Israel had in common with its neighbours, with the divine commandments in the 'Bundes-Ethik' of Sinai. Thus Old Testament is determined by the "Selbstoffenbarung des Bundegottes in der geschichtlichen Führung Israels". More recently Walter C Kaiser (1983), like Eichrodt, assumes that Old Testament ethics can be interpreted in unified and systematic ways and that it stills holds moral authority for modern Christians as divine commands.

Johannes Hempel (1962:153-161; 1938/1964) reveals a deontological dimension in his discussion of Old Testament ethics by describing the main point of Old Testament ethics as "man shall be like God in his life's conduct according to God's love and truth within the covenant. But he is not allowed to become like God in the sphere of power and knowledge. Both belong together." The description of the communication of the Decalogue as part of the theophany on Sinai, according to Exodus 19-20, forms the bedrock for the subsequent Covenant Code and is a sterling example of the deontological trend in much of the Old Testament reflections on ethical and moral conduct.

In many of the early priestly writings and most of the earlier wisdom traditions there is a conformity to a pattern of natural order (resembling 'natural law') which amounts to the conviction that creation "works according to moral principles" of which God is the only source and guarantor (Barton 1978:60).

\section{Teleological or Consequentialist Ethics in the Old Testament}

According to teleological ethics the ends or consequences of an act determines if an act is good or evil. ${ }^{17}$ As one can expect, there is a difference of opinion about what ends or goals actions ought to promote: eudaemonist ethics seek happiness as the result of the nurturing of the classical virtues (courage, justice, temperance and wisdom); while utilitarian theories came up with the motto "greatest pleasure for the greatest number" (Darwall 2002).

Eudaemonist ethics run into serious trouble when it encounters examples where a life of virtue does not lead to happiness but to suffering (i.e. Job, Jesus and Socrates). Utilitarian

\footnotetext{
16 Walter C Kaiser (1983) is but one example of previous discussions that deliberately contrasted Old Testament ethics with philosophical ethics.

17 This type of ethic is summarised by the well-known saying: "the ends justify the means."
} 
ethics are constantly challenged by charges that all ends do not justify the means (Mill 1998).

Casuistic law in the Old Testament provides many examples of teleological ethics (If so ... then ...). The book of Deuteronomy has numerous references of obedience to the revealed will of God (Dt 10:12-15) as the basic rationale of ethical reflection in the deuteronomistic parts of the Old Testament (Barton 1978:59-60; Millar 1998).

The moral orientation to conform to the revealed will of God is also reflected in the prophetic concern for justice (Hs 4:6; Mi 6:8). Under the influence of German scholars such as Julius Wellhausen (1889) it has been assumed that there was an evolutionary development of ethical reflection in the Old Testament, reaching its zenith with the prophets. As far back as 1895 WS Bruce traced this 'ethical progress' in the Old Testament by citing the prophets as examples of 'new moral content' that consisted of combining 'the love of God' with the 'fear of God', as well as regulating all individual and communal actions by 'fidelity and righteousness'. 18

Otto (1994) disagrees with scholars such as Wellhausen who considered the prophets as the ethical apex of Old Testament thought and who had far less appreciation for legal traditions that were presumed to be the result of post-exilic Judaism. He is quite frank that he considers his understanding of Old Testament ethics to emerge out of the Jewish legal tradition reflected in the Hebrew Bible and that he wants to shy away from any suggestion of anti-Semitism (12-17). The legal traditions of the Old Testament have a clear theological agenda and do not smack of a superficial and legalistic piety. On the contrary, Otto demonstrates the existence of ethical, justice and liberation themes to be present in major chunks of Israel's legal heritage.

\section{Perfectionist or Virtue Ethics in the Old Testament}

Apart from the duty to rules (deontology) and the derivation of right and wrong from the outcome of an act (consequentialism), virtue ethics strikes a new balance between ethical concerns by focusing on the influence of character and virtue on ethical behaviour and decision making.

In general, virtue ethics emphasizes the character of the moral agent and pays less attention to the nature and consequences of the action in question. ${ }^{19}$ Philosophers and theologians as diverse as Aristotle, Aquinas, Spinoza and Marx have in common that, in one way or the other, they adhered to perfectionist ethical theories that characterize human good in terms of the development of human nature within the context of different communities. $^{20}$

Bruce Birch (1988:75-91) emphasizes the ability of the Old Testament narratives to influence the modern Christian's morality and character by challenging the reader to respond. "No amount of appeal to abstract principles in Christian ethics and calls to Christian decision making and action based on those principles will be of much use if the shaping influence of our biblical faith stories is not a formative part of our identity" (Birch 1988:79).

18 See also the discussion of the ethics by Old Testament prophets by E Hammershaimb (1960:75-101).

19 Aristotle identified several virtues that influenced virtue ethics up to this day: wisdom (both theoretical and practical), prudence, justice, courage, temperance and fortitude (Nicomachean Ethics, Book I).

20 In his very influential reappraisal of Aristotelian ethics, After Virtue, Alisdair MacIntyre (1984) pointed out that virtues are generated by a community, grounded in time and place. 'Ethics' indicate reflection on the existing 'ethos' of a community - a distinction often neglected in surveys of Old Testament ethics. 
Following in the footsteps of Hauerwas and Birch, it is argued by Waldemar Janzen (1994) that Old Testament narratives are far more formative for ethics than Law. He does this by proposing that there were certain normative and formative paradigms of behaviouri.e. the royal, priestly, prophetic, wisdom and above all the family paradigm. The last (family) paradigm mentioned "underlies the others and holds them together through a common emphasis on life, land and hospitality" (Wright 2004:431).

\section{Descriptive Ethics}

In a somewhat subversive and even deconstructive perspective on Old Testament ethics, Cyril S Rodd (2001) is highly critical of many Old Testament ethicists who have been highly selective in what they select from the Old Testament for 'contemporary ethical advocacy' (Wright 2004:439). Any study of Old Testament ethos or ethics must be acutely aware of the 'strangeness' of Old Testament culture. Therefore Rodd cannot accept that the Old Testament can be used as a normative authority for modern ethics in view of all its ethical problems and exceptions to the rule. His sobering conclusion is: "in our glimpses of this strange land we will find that the Bible can offer assistance in our attempt to solve the many puzzling moral questions which face us today... though how we do it or what assistance the Old Testament can provide remains a mystery" (Rodd 2001:327-329).

In similar vein Eckart Otto (1994:10-12) makes a clear distinction between biblical theology, history of religion and biblical ethics. The latter is based on norm or value systems found in the Old Testament and the religious history of ancient Israel and the early Jewish faith communities. In no uncertain terms Otto argues for the descriptive character of Old Testament ethics and his prime concern is not the relevance of Old Testament ethics for his own society. The vast historical divide between 'then' and 'now' prohibits the immediate application of Old Testament norms in the present. Grappling with contemporary problems is left to academic disciplines such as Sociology, Law and Economics (Otto 1994:10). To be fair - there are several examples where Otto does attempt to establish some modern relevance for Old Testament ethics. A clear warning against the 'unhistorische Systematisierung' of Old Testament ethics is based on the premise that the unity that does exist in the ethics of the Old Testament is of a historical nature - as Otto (1994:120) concluded: 'Die Einheit ... ist ihre Geschichte.'

Otto seems to have a matching lack of interest in the ethical implications of the narratives in the Pentateuch and the narrative ('historical') sections of the so-called Former Prophets. The potential of Old Testament narratives/stories as a source of moral formation is largely absent in this monograph on Old Testament ethics - vide the research done by Bruce Birch (1991), already mentioned. The old question also rears its head: should ethics be concerned only with moral decisions or should ethics also address the character formation of the moral agents involved in current decision making?

\section{Conclusion}

In conclusion, it will be suggested that the surveys of the recent studies of Old Testament ethics might assist the current theological-ethical debate in South Africa about moral concerns. In South Africa we encounter the combination of several ethical traditions and 
some meta-critical clarity about the underlying hermeneutical presuppositions can stimulate better mutual understanding without assuming inevitable consensus. ${ }^{21}$

On the one hand, there is an ethical tradition from Europe and so-called Western Culture according to which the need to respect and protect human life and individual freedom is taken for granted (shades of deontological ethics). ${ }^{22}$ On the other hand, there are ethical traditions emanating from different parts of Africa that are reflected in the focus on the common good of the community (an ubuntu type of teleological ethic). ${ }^{23}$

Ethical reflection on the Old Testament in South Africa is challenged by the striking of some balance between individual and communal or social interests. The balance of these interests can be challenged critically and creatively by an important and pervasive element of Old Testament ethos: that the worship of one God implies being sensitive to and taking responsibility for the integrity of others, not only as individuals but also as a community. The old question again rears its head: should Old Testament ethics be concerned only with moral decisions and at least the description thereof or should Old Testament ethics also address the character formation of the moral agents involved in current decision making?

Perhaps the richness and diversity of Old Testament ethics (which includes teleological, deontological and perfectionist ethical perspectives relating to the same God but within different social communities) can inform the moral dialogue of South African faith communities in a creative and critical manner. Twenty years after the first fully democratic election in South Africa one of the most important aspects of the unfinished agenda of the Old Testament guild of scholars in South Africa is to shoulder at least co-responsibility to strengthen the moral backbone of a nation that is ravaged (amongst others) by corruption, self-centredness and a weak work ethic!

This responsibility to inculcate the virtues of theoretical wisdom (sophia) and practical wisdom (phronesis) in society can come to fruition if the study of Old Testament ethics establishes creative dialogue with philosophical meta-ethics and maintains critical continuity with existing Old Testament scholarship and diverging local interpretive communities - a daunting but exciting opportunity!

21 The current debate about the issue of land ownership and restitution in South Africa is a good example of how diverging attitudes about individual and communal ethics make mutual understanding difficult if not impossible.

22 The Western emphasis on individual rights and ethics is well illustrated by the preamble to and the thirty articles of the "Universal Declaration of Human Rights" that was adopted by the United Nations General Assembly on 10 December 1948 in Paris. The Preamble starts with "Whereas recognition of the inherent dignity and of equal and inalienable rights of all members of the human family is the foundation of freedom, justice and peace in the whole world." This is explained in the subsequent thirty articles in which several illustrate the emphasis on the rights of the individual: Article 1: "All human beings are born free and equal in dignity and rights." Article 2: "Everyone is entitled to all rights and freedoms set forth in this Declaration, without distinction of any kind..."Article 3: "Everyone has the right to life, liberty and security of person." Proponents of 'Ubuntu' argue that the dignity of individual human beings is rooted in society because "a person is a person through other people." Desmond Tutu (1999:31-32) provides the following description of the concept of 'Ubuntu' that has obvious ethical implications: "A person with Ubuntu is open and available for others, affirming of others, does not feel threatened that others are able and good, based on a proper selfassurance that comes from knowing that he or she belongs to a greater whole and is diminished when others are humiliated or diminished, when others are tortured and oppressed." 


\section{BIBLIOGRAPHY}

Arneth, M 2013. "Der Exodus der Sklaven," Kerygma und Dogma 59:109-124.

Arndt, E 2011. Demanding Attention. The Hebrew Bible as a Source for Christian Ethics. Grand Rapids: Eerdmans.

Aristotle, 1908-1952. The Works of the Bible, in DA Knight (ed.), Ethics and Politics in the Hebrew Bible (Semeia 66). Scholars Press, 17-20.

Barton, J 2003. Understanding Old Testament Ethics. Approaches and Explorations. Louisville: Westminster/John Knox.

Birch, BC 1991. Let Justice roll down. The Old Testament, Ethics and Christian life. Louisville: Westminster/John Knox.

Birch, BC 2007. "Ethics in the OT," in The New Interpreter's Dictionary of the Bible D-H Volume 2. Nashville: Abingdon, 338-348.

Bosman, HL 1994. "Problems and prospects of the theological-ethical interpretation of the Old Testament", OTE 7(4):259-266.

Bruce, WS 1895. The ethics of the Old Testament. London: Hammond.

Bruckner, JK 2003. "Ethics", in Dictionary of the Old Testament. Pentateuch. Downers Grove: InterVarsity, 224-240.

Bullock, CH 2008. "Ethics", in T Longman III \& P Enns (eds.) Dictionary of the Old Testament. Wisdom, Poetry \& Writings. Downers Grove: IVP Aristotle (ed. WD Ross) 12 Volumes. Oxford: Clarendon.

Barton, J 1978. "Understanding Old Testament Ethics”, JSOT 9:44 -64.

Barton, J 1983. "Approaches to Ethics in the Old Testament” in John Rogerson (ed.), Beginning Old Testament Study. London: SPCK, 113-130.

Barton, J 1995. "The Basis of Ethics in the Hebrew, 193-200.

Childs, BS 1992. Biblical Theology of the Old and New Testaments: Theological Reflection on the Christian Bible. London: SCM.

Darwall, S (ed.) 2002. Consequentialism. Oxford: Blackwell.

Davies, EW 2008. "The Bible in Ethics," in JW Rogerson \& JM Lieu (eds.), The Oxford Handbook of Biblical Studies. Oxford: OUP, 732-753.

Davies, EW 2010. The Immoral Bible. Approaches to Biblical Ethics. London: T\&T Clark.

Eco, U 1981. The Role of the Reader: Explorations in the Semiotics of Texts. London: Hutchinson.

Eichrodt, W 1933-39. Theologie des Alten Testaments 3 vols. Leipzig: JC Hinrichs.

Eichrodt, W 1967. Theology of the Old Testament Vol 2. London: SCM.

Fetterley, J 1978. The Resisting Reader: A Feminist Approach to American Fiction. Bloomington: Indiana University Press.

Fish, SE 1980. Is there a Text in this Class? The Authority of Interpretive Communities. Cambridge: Harvard University Press.

Gammie, JG 1974. "Spatial and Ethical dualism in Jewish wisdom and Apocalyptic Literature", JBL 93:356-385.

Goldingay, J 1991. Approaches to Old Testament interpretation. Leicester: Apollos. Habermas, J 1981. Theorie des kommunikativen Handelns 2 vols. Frankfurt: Reiner. 
http://scriptura.journals.ac.za

A Survey of Old Testament Ethical Reflection Informed by Philosophical Ethics

Hammershaimb, E 1960. "On the ethics of the Old Testament prophets", VTSup 7:75-101.

Hempel, J 1962. "Ethics in the OT", in The Interpreter's Dictionary of the Bible. New York: Abingdon, 153-161.

Hempel, J 1938/1964. Das Ethos des Alten Testaments (BZAW 67), 2nd edition. Berlin: Töpelmann.

Iser, W 1974. The Implied Reader: Patterns of Communication in Prose Fiction from

Bunyan to Beckett. Baltimore: Johns Hopkins University Press.

Jauss, HR 1982. Toward an Aesthetic of Reception. Minneapolis: University of Minnesota Press.

Janzen, W 1994. Old Testament Ethics. A paradigmatic approach. Louisville:

Westminster/John Knox.

Kaiser Jr, WC 1983. Toward Old Testament Ethics. Grand Rapids: Zondervan.

Kaiser Jr, WC 1992. "New Approaches to Old Testament Ethics“, JETS 35:289-297.

King, I 2008. How to make good decisions and be right all the time. London: Continuum.

Koch, K 1955. Gibt es ein Vergeltungsdogma im Alten Testaments? ZTK 52:1-42.

Kuhn, TS 1962. The Structure of Scientific Revolutions. Chicago: Chicago Univ Press.

MacIntyre, A 1984. After Virtue: A Study in Moral Theory. Chicago: Notre Dame University Press.

Mein, A 2001. Ezekiel and the Ethics of Exile. Oxford: Clarendon.

Mill, JS 1998. Utilitarianism. Oxford: Oxford University Press.

Millar, JG 1998. Now choose life: Theology and Ethics in Deuteronomy.

Leicester: Apollos.

Mills, ME 2001. Biblical Morality. Moral perspectives in Old Testament narratives.

Moral perspectives in Old Testament narratives. Aldershot: Ashgate.

Moyise, S 2004. Introduction to Biblical Studies (2nd edition). London: T\&T Clark.

Muilenburg, 1961. The way of Israel: Biblical Faith and Israel. New York: Harper.

Otto, E 1991. "Forschungsgeschichte der Entwürfe einer Ethik im Alten Testament", VF 36:3-37.

Otto, E 1994. Theologische Ethik des Alten Testaments. Stuttgart: Kohlhammer.

Oyen, H van 1967. Die Ethik des Alten Testaments. Gütersloh: Mohn.

Rodd, CS 2001. Glimpses of strange land. Studies in Old Testament Ethics.

Edinburgh: T\&T Clark.

Rogerson, J 2004. Theory and Practice in Old Testament Ethics (JSOTS 405).

London: T\&T Clark.

Sanders, JA 1972. Torah and Canon. Philadelphia: Fortress Press.

Sanders, JA 1980. "Canonical Context and Canonical Criticism," HBT 2:173-197.

Smend, R 1995. ”Ethik III: Altes Testaments“. TRE 10:423-435.

Tutu, DM 1999. No Future without Forgiveness. New York: Image Books, Doubleday.

Uleman, J 2010. An Introduction to Kant's Moral Philosophy. Cambridge:

Cambridge University Press.

Verhey, A 2005. "Ethics," in KJ van Hoozer (ed.), Dictionary for Theological

Interpretation of the Bible. Grand Rapids: Baker Academic, 196-200. 
Weber, M 1988. "Die soziale Gründe des Untergangs der antiken Kultur" in Gesammelte Aufsätze zur Sozial- und Wirtschaftsgeschichte. Tübingen: Mohr Siebert.

Wellhausen, J 1889. Die Composition des Hexateuchs und der historischen Bücher des Alten Testaments (2nd edition). Berlin: Georg Reimer.

Wenham, GJ 2000. Story as Torah: Reading the Old Testament ethically. Edinburgh: T\&T Clark.

Wilson, RR 1988. “Approaches to Old Testament Ethics”, in Tucker, GM (ed.) et al. Canon, Theology and Old Testament Interpretation. Philadelpia: Fortress, 62-74.

Wright, CJH 1983. Living as the People of God. The relevance of Old Testament ethics. Leicester: InterVarsity Press.

Wright, CJH 2004. Old Testament Ethics for the people of God. Downers Grove: InterVarsity.

Wright, CJH 2005. "Ethics", in BT Arnold \& HGM Williamson, Dictionary of the Old Testament. Historical Books. Downers Grove: InterVarsity Press, 259-268. 